Beobachtungsreihen lassen es wabrscheinlich erscheinen, dass ein periodischer Fehler in den Declinationen des A. G. C. thatsächlich existirt, wenigstens für die mittlere Declination $+52: 5$, und zwar mit der ganzen Amplitude von etwa 0.3 . Ich möchte jedoch meine Resultate nicht als entscheidend ansehen, vielmebr anregen, dass die Frage durch neue, speciell auf diesen Zweck hin mit möglichster Vermeidung systematischer Fehlerquellen unternommene Reihen definitiv entschieden werden möge. Man würde Beobachtungsplätze auszuwählen haben, an welchen Refractionsanomalien nicht zu befürchten sind, und man würde sich zunächst am besten auf Sterne in möglichster Nähe des Zeniths beschränken; vielleicht dürfte es sich empfehlen die Beobachtungen völlig im Freien auszuführen. Selbstverständlich muss ein sehr scharfer Anschluss der benutzten Sterne an das System des A. G. C. durch Meridiankreis-Beobachtungen hinzukommen.

Wenn die Prüfung der Gleichförmigkeit eines Declinationssystems durch die Horrebow-Beobachtungen sich bewährt, so scheinen mir letztere in Verbindung mit Meridiankreis-Beobachtungen auch zur Bestimmung absoluter mittlerer Declinationen verwandt werden zu können, und zwar auch an Orten, an welchen Nadireinstellungen nicht möglich sind. Die aus den Polhöhenbestimmungen, also vermittelst der Horrebow-Libelle, abgeleiteten Reductionen auf Gruppenmittel und Gruppenreductionen reduciren die etwa willkürlich angenommenen Declinationsmittel der einzelnen Paare auf ein in sich einheitliches System, etwa auf das mittlere Decli. nationssystem der neun Gruppen. Die reducirten Declinationsmittel sind nicht absolut richtige Declinationen; aber sie werden durch Addition einer für alle constanten, jedoch vorläufig unbekannten Correction $x$ in die absolut richtigen Declinationen verwandelt. Die Reductionen bestimmen mit anderen Worten einen wahren Parallel am Himmel, dessen absolute Declination uns jedoch unbekannt ist.

Messen wir am Meridiankreise den Abstand eines

Berlin, 1898 October 2 .
Polsterns von dem in oberer Culmination befindlichen Punkt dieses wahren Parallels sowohl bei oberer als auch bei unterer Culmination des Polsterns, so erhalten wir daraus in bekannter Weise die absolute Declination des Polsterns und des wahren Parallels. Wir beobachten also am Meridiankreise einen Polstern und anschliessend eins der Horrebow-Paare, beide in oberer Culmination; ein anderes Mal beobachten wir denselben Polstern in unterer Culmination und anschliessend ein zweites der Horrebow-Paare, dieses aber wieder in oberer Culmination. Die auf das einheitliche Declinationssystem reducirten Declinationsmittel der Horrebow-Paare dienen dabei zur Bestimmung der Aequatorpunkte. Wir erhalten die absolute Declination $\delta$ des Polsterns bei seiner oberen Culmination in der Form $\delta=a+x$, bei seiner unteren Culmination in der Form $180^{\circ}-\delta=b+x$, wo $a$ und $b$ durch die Beobachtungen gegeben sind. Wir erhalten die absolute Declination des Polsterns durch die Formel

$$
d=90^{\circ}-1 / 2(b-a)
$$

und die constante Correction des angenommenen Declinationssystems (also etwa des mittleren Declinationssystems der sämmtlichen Gruppen) durch die Formel

$$
x=90^{\circ}-1 / 2(b+a) \text {; }
$$

die Horrebow-Beobachtungen ergeben dann die absolute Polhöhe.

Diese Methode durch Bestimmung eines wahren Parallels ist naturlich complicirter als die gewöhnliche durch Nadirbestimmung. Die Einstellungen der Sterne des Paares sind auch ungenauer als die Nadireinstellungen; dafür kann man mehrere benachbarte Horrebow. Paare am Meridiankreise beobachten und vermeidet den constanten Theilungsfehler des Nadirpunktes. Ferner wird man unabhängig von der Polhöhenänderung. Die Methode ergiebt aber nur die mittleren Declinationen absolut und setzt dabei die Reductionselemente als genügend bekannt voraus.

\section{H. Battermann.}

\title{
Additional Observations of (433) Eros.
}

(Harvard College Observatory Circular No. 37).

The method of search for Eros, (433), described in A. N. 3540 , has been continued. The ephemeris has been extended by $\mathrm{Mr}$. Chandler, as required, and images of the planet have been found by the writer on thirteen plates. From these images the following approximate positions have been determined in addition to those given in A. N. 3540 . The successive columns give the number of the plate, the date, the Greenwich Mean Tine of the middle of the exposure, the length of the exposure in minutes, and the approximate right ascension and declination for 1875 . These positions are, in general, derived from adjacent Durchmusterung stars. Preparations are now being made for precise determinations of the positions of the planet on these plates, and on those described in A. N. 3540. The last two columns give the anomaly and the computed photographic magnitude, assuming the magnitude at distance unity, 12.0, as derived from the measures given in A. N. 3526 . The correction for phase is necessarily omitted, and may exceed a magnitude, as the phase angle may amount to $60^{\circ}$. The last three plates

\begin{tabular}{|c|c|c|c|c|c|c|c|c|}
\hline \multicolumn{2}{|c|}{ Plate } & Date. & G. M. T. & Exp. & $\alpha 1875$ & 81875 & $v$ & Magn. \\
\hline I & 9801 & 1893 Oct. 28 & $21^{h} 55^{m}$ & $14^{\mathrm{m}}$ & $5^{h} 5^{8 m} .8$ & $+53^{\circ} 40^{\circ}$ & $-71^{\circ}$ & 10.9 \\
\hline I & $9^{8} 3^{2}$ & 1893 Oct. 30 & $20 \quad 18$ & Io & $64 \cdot 5$ & +546 & -69 & 10.8 \\
\hline I & 9862 & 1893 Oct. 31 & 2121 & 15 & 7.6 & +5720 & -69 & 10.8 \\
\hline 1 & 10095 & 1893 Nov. 26 & $20 \quad 26$ & 17 & $7 \quad 17 \cdot 7$ & +5750 & -49 & 9.9 \\
\hline
\end{tabular}
were taken at Arequipa, all of the others at Cambridge. 


\begin{tabular}{|c|c|c|c|c|c|c|c|c|}
\hline \multicolumn{2}{|c|}{ Plate } & Date. & G. M. T. & Exp. & $\alpha 1875$ & 81875 & $z$ & Magn. \\
\hline I & 10280 & x 893 Dec. 23 & $19^{\mathrm{b}} 49^{\mathrm{m}}$ & $13^{m}$ & $7^{\mathrm{h}} 45^{\mathrm{m}} \cdot 7$ & $+5^{\circ} 5^{8^{\prime}}$ & $-26^{\circ}$ & 8.8 \\
\hline I & 10407 & 1894 Jan. 8 & 188 & 65 & $735 \cdot 5$ & +4123 & -12 & 8.4 \\
\hline I & 10469 & 1894 Jan. 19 & 1657 & IO & 726.5 & +2846 & -3 & 8.2 \\
\hline I & 10559 & 1894 Jan. 25 & 1616 & I 3 & 723.6 & +2115 & + & 8.2 \\
\hline I & 10604 & 1894 Jan. 30 & I 340 & 60 & 722.5 & +1520 & +7 & 8.3 \\
\hline A & 222 & 1894 Febr. 5 & 1526 & 60 & $7 \quad 23.3$ & $+84^{6}$ & +12 & 8.4 \\
\hline B & 11174 & 1894 May 19 & 1416 & 10 & 1038.0 & - I4 57 & +91 & I I 9 \\
\hline B & 16518 & 1896 June 29 & 1917 & 15 & I 737.8 & $-3^{6} 22$ & $+15^{2}$ & 12.5 \\
\hline $\mathbf{A}$ & 1876 & 1896 June 30 & 1346 & 60 & $173^{6.4}$ & -36 I 2 & +152 & 12.5 \\
\hline
\end{tabular}

I 9801 . This photograph is important since with that taken on May 19, 1894, the anomaly through which the planet was observed in $1893-1894$ becomes $162^{\circ}$. The observations contained in A. N. $354^{\circ}$ extended over an angle of $101^{\circ}$.

I ro280. Plate dark, and difficult to measure.

I 10407 . Faint spectrum on edge of plate.

I ro469. This plate was fogged and was so dark that it was marked useless. Its density was about that of a shade glass used in viewing the Sun. By making a double contact print from it a photograph is obtained on which accurate measurements of the planet are possible.

I 10604. Spectrum. Superposed on spectrum of $+15^{\circ} 1581$, Magn. 9.5.

A 222. Well marked trail $160^{\prime \prime}$ long, showing irregularities in running of driving clock of telescope.

B I I 174 . See I 9801 .

A 1876 . Well marked trail. At about $13^{\mathrm{h}}{ }^{1} 5^{\mathrm{m}}$ the planet would have coincided very nearly with $-36^{\circ} 11846$. The orbit of the planet could be well determined from the observations in 1896 alone, using for the first place the position of April 6 , for the second the three positions on June 4 and June 5 , given in A. N. $354^{\circ}$, and for the third, this photograph with that taken on June 29.

Some important conclusions may be derived from this investigation. All the photographs on which the planet has been found were taken with doublets. If they had been taken with lenses of the usual form with a field $2^{\circ}$ in diameter all of the images would have fallen outside of the plates. In view of the difficulties found in photographing this object with an ordinary lens at Greenwich and Oxford (Observatory XXI, 249) it is doubtful whether we should have obtained many images of it here with such a lens, even if it had been in regions photographed. The number of plates on which the planet appears probably fairly represents the number we have of all other similar objects whether already discovered or not. This planet is bright during only a small portion of time. During the last eleven years it has been brighter than the ninth magnitude, photographically, for only two months, or about a seventieth part of the entire time. There may be other similar objects, even brighter, as yet undiscovered. Nova Aurigae was as bright as the fifth magnitude for six weeks before it was discovered. Had Eros attained the sixth magnitude instead of the eighth it should have appeared on plates taken with the transit photometer. In this case, we should have had an image of it on every clear night on which it culminated after dark. Fairly good positions could have been obtained from these images since the focal length of the telescope is about two feet, and the exposures are so short that the images are always circular. We have now a similar instrument in Arequipa so that in general two images should be obtained every night.

Harvard College Observatory, 1899 January 16.

Edward C. Pickering.

\section{Schreiben von Prof. E. Millosevich an den Herausgeber betr. neue Elemente des Planeten (433) Eros.}

Ora che conosciamo gli elementi ellittici, calcolati dal chiarissimo prof. Chandler, di (433) Eros coll' intervallo $1893-4-1898$, benchè non tenuto conto delle perturbazioni, non le dispiacerà di conoscere il terzo mio sistema sulla base di $128 \mathrm{di}$, l'ultima osservazione essendo del Dr. Cerulli, il 20 dicembre. Gli elementi sono dedotti col metodo della variazione delle distanze, utilizzando le osservazioni fotografiche di Greenwich. Essi mi serviranno come base di partenza per dedurre da tutte le osservazioni della presente opposizione gli elementi i più probabili.

Roma, 1899 Gennajo $x_{4}$.
Epoca 1898 Agosto $3 \mathrm{I.5}$ B.

$$
\begin{aligned}
& M=221^{\circ} 40^{\prime} 29^{\prime \prime} 6 \\
& \omega=177 \quad 36 \quad 7.3 \\
& \Omega=30329 \quad 50.9 \\
& i=104933.1 \\
& \varphi=125225.4 \\
& \mu=2014.656
\end{aligned}
$$

Chandler - M.

$$
\begin{array}{lc}
5^{\prime} & 59.0 \\
+\mathrm{I} & 48.7 \\
-2 & 6.2 \\
+0 & 38.7 \\
-0 & 15.6 \\
+ & 0.577
\end{array}
$$

E. Millosevich.

Inhalt zu Nr. 3545. H. Battermann. Ableitung der Aberrationsconstante, der mittleren Polhöhe, und einer von der Rectascension abhängigen Periode in den Declinationen des Fundamental-Catalogs der A. G. 257. - E. C. Pickering. Additional Observations of (433) Eros. 269. - E. Millosevich. Schreiben an den Herausgeber. $27 \mathrm{I}$. 